\title{
EFFECT OF ISOFLURANE ANAESTHESIA AND SURGERY \\ ON CARBOHYDRATE METABOLISM AND PLASMA CORTISOL LEVELS IN MAN
}

\author{
Tsutomu Oxama, Peter Latto, and Duncan A. Holaday
}

\section{INTRODUCTION}

Carbohydrate metabolism and plasma levels of growth hormones (GH) and insulin are influenced differently by different volatile anaesthetic drugs. ${ }^{1-3}$ The present study was undertaken to investigate the effects of isoflurane anaesthesia and surgery on plasma concentrations of $\mathrm{GH}$, insulin, glucose and cortisol to determine their influence on carbohydrate metabolism.

\section{Methods}

Nine male patients ranging in age from 25 to 56 years were the subjects of the study (Table I). No patients were included who had hepatic, renal, endocrine, or cardiovascular disease. They were all premedicated with pentobarbitone $100 \mathrm{mg}$ and atropine $0.5 \mathrm{mg}$ intramuscularly one hour before anaesthesia. Denitrogenation was carried out for ten minutes using 100 per cent oxygen.

Anaesthesia was induced with intravenous thiopentone $3-5 \mathrm{mg} / \mathrm{kg}$, and tracheal intubation was performed after intravenous administration of succinylcholine 100 mg. Liquid isoflurane was injected from a $20 \mathrm{ml}$ gas-tight Hamilton syringe into a leak-free closed circle system with carbon dioxide absorption. The injection was made by a variable speed syringe pump which was controlled by a Data-Trak curve follower (Dose Regulated Anesthesia, Mark II, Quan. Inc.). The infusion was programmed to provide an alveolar isoflurane concentration equivalent to approximately $1.3 \times \mathrm{MAC}$ ( $\mathrm{MAC}=1.27$ per cent). Oxygen was added to the circuit at a rate of approximately $250 \mathrm{ml} /$ minute to match metabolic consumption. The patient's ventilation was controlled by an Ohio Ventilator $(300 \mathrm{D} / \mathrm{O})$. The patient's $\mathrm{Pa}_{\mathrm{O}_{2}}$ and $\mathrm{Pa}_{\mathrm{CO}_{2}}$ remained within the normal range, as determined by periodic blood gas analysis.

Adequate muscle relaxation was obtained with d-tubocurare. Four arterial samples of 2 to $3 \mathrm{ml}$ were taken during anaesthesia and analyzed by gas chromatography for isoflurane concentration. One $\mathrm{ml}$ of blood was equilibrated with $1 \mathrm{ml}$ of hexane; $0.3 \mathrm{ml}$ aliquots of hexane were then injected into a Hewlett-Packard high efficiency gas chromatograph (Model 7610A) fitted with a hydrogen flame. Mean arterial isoflurane concentration was $13.0 \mathrm{mg} \%($ SEM $=1.2$ ) at 30 minutes after

From the Department of Anesthesiology, University of Miami School of Medicine and the Veterans Administration Hospital, Miami, Florida.

Address reprint requests to Professor Tsutomu Oyama, M.D., Department of Anaesthesia, Hirosaki University School of Medicine, Hirosaki, Aomori-Ken, Japan. 
TABLE I

Patients Studied and Operations Performed

\begin{tabular}{|c|c|c|c|c|}
\hline $\begin{array}{c}\text { Patient } \\
\text { no. }\end{array}$ & Age & $\underset{(\mathrm{kg})}{\text { Weight }}$ & $\begin{array}{c}\text { Surgical } \\
\text { operation }\end{array}$ & $\begin{array}{l}\text { Duration of } \\
\text { anaesthesia } \\
\text { (min) }\end{array}$ \\
\hline 1 & 28 & 65 & $\begin{array}{l}\text { Inguinal } \\
\text { herniorrhaphy }\end{array}$ & 100 \\
\hline 2 & 52 & $9 j$ & $\begin{array}{l}\text { Inguinal } \\
\text { herniorrhaphy }\end{array}$ & 101 \\
\hline 3 & 24 & 72 & $\begin{array}{l}\text { Inguinal } \\
\text { herniorrhaphy }\end{array}$ & 92 \\
\hline 4 & 24 & 64 & $\begin{array}{l}\text { Inguinal } \\
\text { herniorrhaphy }\end{array}$ & 77 \\
\hline 5 & 56 & 66 & Lumbar laminectcmy & 156 \\
\hline 6 & 39 & 99 & Lumbar laminectomy & 209 \\
\hline 7 & 42 & 74 & Osteotomy fibula & 165 \\
\hline 8 & 46 & 79 & $\begin{array}{l}\text { Ventral incisional } \\
\text { herniorrhaphy }\end{array}$ & 103 \\
\hline 9 & 56 & 85 & $\begin{array}{l}\text { Ventral hernia } \\
\text { repair }\end{array}$ & 160 \\
\hline
\end{tabular}

the induction and one hour after the start of surgery, respectively. One liter of normal saline was infused intravenously throughout the procedure.

Immediately prior to anaesthesia, $8 \mathrm{ml}$ of venous blood was collected in a heparinized syringe, rapidly transferred to a test tube and centrifuged within 30 minutes of collection. Additional blood was sampled at the following times: (1) 5 minutes before induction of anaesthesia; (2) 15 and 30 minutes after the induction, but before the start of surgery; (3) 1 hour after the start of surgery; and (4) in the recovery room after the patient has recovered adequately from anaesthesia. To avoid diurnal variation of plasma cortisol levels, anaesthesia was induced at about 7:20 a.m. One $\mathrm{ml}$ of plasma from each blood sample was stored at $-20^{\circ} \mathrm{C}$ and thawed within one month just prior to radioimmunoassay for growth hormone $(\mathrm{GH})$ and insulin. One $\mathrm{ml}$ of plasma was used for the analysis of plasma cortisol, and $0.2 \mathrm{ml}$ of blood was used to measure blood glucose.

Determination of plasma $\mathrm{GH}$ and insulin were made according to the method of Schalch and Parker, ${ }^{4}$ and Morgan and Lezarow, ${ }^{5}$ respectively. Duplicate determinations were made on all specimens and the mean values were taken. The recovery rate for $\mathrm{GH}$ was 98 per cent and for insulin 94 per cent, indicating adequate reliability. The plasma concentrations of cortisol were determined by fluorimetric assay by Rudd's method ${ }^{8}$ with a Farrand spectrofluorimeter. Duplicate error was $\pm 1.2 \mathrm{mcg} / 100 \mathrm{ml}$ of plasma which appeared reliable for analysis of our data.

\section{Results}

\section{Plasma Growth Hormone}

The mean GH levels in plasma in the nine subjects are shown in Table II. The mean value was $1.26 \pm 0.32(\mathrm{SE}) \mathrm{ng} / \mathrm{ml}(\mathrm{ng}=\mathrm{m} \mu \mathrm{g}) 5$ minutes before induction 
TABLE II

Effects of Isoflurane Anaesthesia and Surgical Operation on Plasma Growth Hormone Levelos in MaN (ng/ml)

\begin{tabular}{cccccc}
\hline \hline & Control & $\begin{array}{c}\text { Post-induction } \\
\text { 15 minutes }\end{array}$ & $\begin{array}{c}\text { Post-induction } \\
30 \text { minutes }\end{array}$ & $\begin{array}{c}\text { Post-incision } \\
\text { 1 hour }\end{array}$ & $\begin{array}{c}\text { Recovery } \\
\text { room }\end{array}$ \\
\hline 1 & 4.00 & 9.4 & 11.7 & 16.8 & 6.5 \\
2 & 1.1 & 5.6 & 5.8 & 1.6 & 1.1 \\
3 & 0.9 & 4.0 & 5.3 & 2.2 & 2.0 \\
4 & 0.9 & 1.2 & 1.5 & 1.2 & 1.5 \\
5 & 0.9 & 9.0 & 27.9 & 18.8 & 3.6 \\
6 & 0.9 & 1.5 & 1.5 & 8.1 & 7.6 \\
7 & 0.9 & 1.3 & 1.3 & 1.9 & 1.0 \\
8 & 0.9 & 4.0 & 6.0 & 4.7 & 1.8 \\
9 & 0.9 & 8.1 & 7.71 & 7.8 & 1.0 \\
Mean & 1.26 & 4.90 & 2.93 & 7.00 & 2.90 \\
SE & 0.32 & 1.04 & 2.170 & 2.09 & 0.78 \\
t & & 3.742 & 0.047 & 2.785 & 2.284 \\
P & & 0.006 & & 0.024 & 0.052 \\
\hline
\end{tabular}

of anaesthesia, which was within normal limits (less than $5 \mathrm{ng} / \mathrm{ml}$ ). The mean presurgical concentrations of $\mathrm{GH}$ in plasma after 15 minutes and 30 minutes of isoflurane anaesthesia increased significantly to $4.90 \pm 1.04$ and $7.71 \pm 2.93 \mathrm{ng} / \mathrm{ml}$, respectively. Plasma levels of $\mathrm{GH}$ remained elevated during surgery (7.00 \pm 2.09 $\mathrm{ng} / \mathrm{ml}$ ). They decreased in the recovery room but were still significantly elevated $(2.90 \pm 0.78 \mathrm{ng} / \mathrm{ml})$.

\section{Plasma Insulin}

The mean control plasma insulin level was $10.3 \mu \mathrm{U} / \mathrm{ml}$. The plasma insulin level increased during isoflurane anaesthesia alone and during surgery, but the increase was not statistically significant (Table III).

\section{Blood Glucose}

The mean control blood glucose concentration was $81.0 \mathrm{mg} / 100 \mathrm{ml}$. This was significantly elevated during isoflurane anaesthesia alone for 15 minutes (103.3 \pm $9.4 \mathrm{mg} / 100 \mathrm{ml}$ ) and 30 minutes $(112.1 \pm 10.2 \mathrm{mg} / 100 \mathrm{ml})$. Mean blood glucose levels further increased during surgery, and the peak level $(133.8 \pm 14.9 \mathrm{mg} / 100$ $\mathrm{ml}$ ) was observed in the recovery room (Table IV).

\section{Plasma Cortisol}

The mean control plasma cortisol level prior to induction of anaesthesia was $17.6 \pm 1.7 \mu \mathrm{g} / 100 \mathrm{ml}$; it increased insignificantly to $20.4 \pm 2.4 \mu \mathrm{g} / 100 \mathrm{ml} 30$ minutes after the induction of isoflurane anaesthesia but before operation. Plasma cortisol level increased significantly during operation $(26.0 \pm 2.3 \mu \mathrm{g} / 100 \mathrm{ml}$ ), and the peak concentration was found in the recovery room $(29.8 \pm 1.7 \mu \mathrm{g} / 100 \mathrm{ml})$, as shown in Table $\mathrm{V}$.

\section{Discussion}

The present study demonstrates that the blood glucose level is increased significantly by 38 per cent after 30 minutes of isoflurane anaesthesia alone. Similar 
TABLE III

EfFects of Isoflurane Anaesthesia and Surgery on Plasma Insulin Levels in Man $(\mu \mathrm{U} / \mathrm{ml})$

\begin{tabular}{cccccc}
\hline \hline & Control & $\begin{array}{c}\text { Post-induction } \\
15 \text { minutes }\end{array}$ & $\begin{array}{c}\text { Post-induction } \\
30 \text { minutes }\end{array}$ & $\begin{array}{c}\text { Post-incision } \\
\text { 1 hour }\end{array}$ & $\begin{array}{c}\text { Recovery } \\
\text { room }\end{array}$ \\
\hline 1 & 7.7 & 4.0 & 11.5 & 10.2 & 14.1 \\
2 & 8.6 & 5.9 & 10.2 & 12.8 & 38.4 \\
3 & 15.4 & 25.6 & 37.7 & 73.6 & 17.7 \\
4 & 5.8 & 5.0 & 5.0 & 8.3 & 8.3 \\
5 & 6.8 & 6.8 & 7.0 & 6.4 & 24.3 \\
6 & 7.4 & 4.0 & 4.0 & 11.5 & 7.4 \\
7 & 8.3 & 5.8 & 8.3 & 18.9 & 5.8 \\
8 & 7.7 & 5.1 & 1.0 & 7.8 & 10.2 \\
9 & 25.1 & 21.1 & 18.4 & 21.0 & 16.6 \\
Mean & 10.3 & 9.2 & 12.7 & 18.9 & 15.8 \\
$\mathrm{SE}$ & 1.94 & 2.55 & 3.64 & 6.62 & 3.23 \\
$\mathrm{t}$ & & 0.717 & 0.574 & 0.362 & 1.452 \\
$\mathrm{p}$ & & 0.494 & 0.574 & 0.185 \\
\hline
\end{tabular}

TABLE IV

Effects of Isoflurane Anaesthesta and Surgery on Blood Glucose Levels (mg/100 ml) in MAN

\begin{tabular}{cccccc}
\hline \hline & Control & $\begin{array}{c}\text { Post-induction } \\
15 \text { minutes }\end{array}$ & $\begin{array}{c}\text { Post-induction } \\
\text { 3C minutes }\end{array}$ & $\begin{array}{c}\text { Post-incision } \\
\text { hour }\end{array}$ & $\begin{array}{c}\text { Recovery } \\
\text { room }\end{array}$ \\
\hline 1 & 90 & 110 & 118 & 152 & 216 \\
2 & 59 & 70 & 72 & 130 & 132 \\
3 & 76 & 92 & 100 & 118 & 176 \\
4 & 84 & 160 & 178 & 196 & 100 \\
5 & 116 & 123 & 118 & 116 & 117 \\
6 & 84 & 101 & 126 & 135 & 88 \\
7 & 96 & 118 & 78 & 90 & - \\
8 & 70 & 76 & 106 & 118 & - \\
9 & 54 & 103.3 & 112.1 & 130.1 & 133.8 \\
Mean & 81.0 & 9.42 & 3.25 & 9.96 & 14.97 \\
SE & 6.36 & 3.15 & 0.01 & 4.51 & 3.11 \\
$\mathrm{t}$ & & 0.02 & 0.01 & 0.02 \\
$\mathrm{p}$ & & & & & 0.01 \\
\hline
\end{tabular}

TABLE $V$

Effects of Isoflurane Anaesthesia and Surgery on Plasma Cortisol Levels $(\mu \mathrm{g} / 100 \mathrm{ml})$ in Man

\begin{tabular}{cccccc}
\hline \hline & Control & $\begin{array}{c}\text { Post-induction } \\
15 \text { minutes }\end{array}$ & $\begin{array}{c}\text { Post-induction } \\
30 \text { minutes }\end{array}$ & $\begin{array}{c}\text { Post-incision } \\
\text { 1 hour }\end{array}$ & $\begin{array}{c}\text { Recovery } \\
\text { room }\end{array}$ \\
\hline 1 & 18.0 & 28.5 & 35.0 & 31.0 & 35.0 \\
2 & 18.0 & 11.5 & 19.0 & 18.5 & 26.5 \\
3 & 15.5 & 17.5 & 11.5 & 17.5 & 39.0 \\
4 & 13.0 & 11.5 & 12.0 & 17.0 & 25.0 \\
5 & 28.5 & 28.5 & 30.0 & 31.0 & 31.0 \\
6 & 13.5 & 14.5 & 18.0 & 37.0 & 33.0 \\
7 & 23.0 & 22.5 & 27.5 & 30.5 & 30.5 \\
8 & 17.0 & 20.0 & - & 27.0 & 22.5 \\
9 & 12.0 & 25.0 & 20.5 & 25.0 & 26.5 \\
Mean & 17.61 & 19.94 & 20.44 & 26.06 & 29.83 \\
SE & 1.76 & 2.23 & 2.40 & 2.37 & 1.77 \\
t & & 1.16 & 1.86 & 3.45 & 5.26 \\
$p$ & & 0.30 & 0.10 & 0.01 & 0.001 \\
\hline
\end{tabular}


hyperglycaemic tendencies were observed during anaesthesia with other anaesthetic agents such as diethyl ether, ${ }^{2}$ but this differs from methoxyflurane, ${ }^{1}$ which does not cause hyperglycaemia. Byles, et al. ${ }^{7}$ and Dobkin, et al..$^{8}$ reported hyperglycaemia during major abdominal surgery under isoflurane anaesthesia, but the effect of isoflurane itself on the blood glucose level was not studied.

We observed that isoflurane anaesthesia itself increased plasma $\mathrm{GH}$ levels. A similar tendency was found during ether, ${ }^{2}$ methoxyflurane, ${ }^{1}$ and halothane anaesthesia. ${ }^{3} \mathrm{GH}$ reached a peak value 30 minutes after the beginning of the operation, confirming previous reports on the effect of surgical stress. Increased GH secretion implies the following: (1) increased uptake of amino acids by many tissues and enhanced synthesis of protein; (2) GH has diabetogenic and anti-insulin effects, which reduces peripheral utilization and uptake of glucose, decreases glucose tolerance, depresses glycolysis, and increases retention of glycogen; and (3) increases lipolysis.

Plasma insulin levels did not change appreciably during isoflurane anaesthesia. This finding was similar to the results with other anaesthetic agents reported previously. ${ }^{1,2.3}$ Hyperglycaemia evokes significant elevation of insulin secretion, ${ }^{9}$ but in our present study it did not significantly increase blood insulin levels during isoflurane anaesthesia and surgical operation.

Possible factors contributing to hyperglycaemia can be divided into those which increase glucose production and those which decrease glucose utilization; hyperglycaemia is the end result of the balance between the rate of production and rate of utilization. Our findings do not exclude a possible role of increased secretion of GH interfering with glucose utilization during isoflurane anaesthesia.

Stimulation of sympathetic nervous activity causes elevation of blood glucose primarily by stimulating hepatic glycogenolysis, and suppresses insulin secretion. This may also have contributed to the hyperglycaemia. Increased secretion of glucocorticoid can also cause hyperglycaemia through a glycogenolytic mechanism. Although the magnitude of hyperglycaemia during isoflurane anaesthesia alone is not great, other anaesthetic agents which do not increase blood glucose may be preferable for patients with severe diabetes. Plasma cortisol level was not increased significantly during isoflurane anaesthesia. In this it is similar to enflurane ${ }^{12}$ and methoxyflurane anaesthesia, ${ }^{10}$ but different from adrenocortical stimulating anaesthetics such as diethyl ether, cyclopropane and halothane. ${ }^{11}$ Normally enhanced adrenocortical activity during a surgical operation was observed under isoflurane anaesthesia. Dobkin, et al. ${ }^{8}$ reported that major surgical stress under isoflurane anaesthesia significantly increased plasma cortisol levels in man, but Byles, et al. ${ }^{7}$ found plasma cortisol concentration decreased from $21 \mu \mathrm{g} / 100 \mathrm{ml}$ to $13 \mu \mathrm{g} / 100 \mathrm{ml}$ after 16 hours of isoflurane anaesthesia in beagles.

\section{SUMMARY}

The present study was undertaken to investigate in nine male surgical patients the effects of isoflurane anaesthesia alone on the carbohydrate metabolism by determining plasma growth hormone $(\mathrm{GH})$, insulin, blood glucose, and cortisol, and to compare them with the effects of anaesthesia associated with surgical opera- 
tions. Determination of plasma $\mathrm{GH}$, insulin, cortisol, and blood glucose were made simultaneously before induction of isoflurane anaesthesia, after maintenance of anaesthesia for 15 minutes and 30 minutes and during and after conclusion of the operation.

Plasma GH concentrations showed a significant elevation during isoflurane anaesthesia, and maintained a similar high level one hour after the start of the operation. An insignificant elevation in plasma insulin level and significant increases in blood glucose were noted during anaesthesia and operation. Plasma cortisol levels increased insignificantly during anaesthesia, but increased markedly during operation. Our observations would suggest that the increased blood level of GH and elevated blood cortisol play a part in the increase of blood glucose during isoflurane anaesthesia and surgical operations in man.

\section{RÉSUMÉ}

Ce travail avait pour objet l'étude des effets de l'Isoflurane seul sur le métabolisme des hydrates de carbone et de les comparer à ceux causés par l'addition du traumatisme chirurgical; à cette find, on a déterminé chez neuf sujets, le taux de l'Insuline, de la Glycémie et du Cortisol. Des échantillons ont été prélevés avant l'induction de l'anesthésie à l'Isoflurane, 15 et 30 minutes après l'induction, avant l'incision, durant et après l'intervention.

On a observé une élévation significative au niveau de l'Hormone de Croissance durant l'anesthésie, élévation qui s'est maintenue une heure après le début de l'intervention. On a également noté au cours de l'anesthésie et de l'intervention une augmentation non significative de l'Insulinémie et une augmentation significative de la Glycémie.

Le Cortisol plasmatique pour sa part s'est élevé de façon non significative durant l'anesthésie, et de façon significative durant le temps chirurgical.

Nos observations suggèrent que l'élévation du taux de l'Hormone de Croissance et du Cortisol joue un rôle dans l'élévation de la Glycémie observée au cours de l'anesthésie à l'Isoflurane chez l'homme.

\section{ACKNOWLEDGMENT}

The authors are thankful for the technical assistance of Paul Doleman, Marta Dominech, of the University of Miami School of Medicine, Miami, Florida, and T. Kudo, B.S., of the Department of Anaesthesia, Hirosaki University School of Medicine, Hirosaki, Japan.

Supported in part by NIH Grants GM 16498-04, GM 16498-05; GM O 1714-07, GM O 1714-08 and a grant-in-aid from Ohio Medical Products.

\section{REFERENCES}

1. Oyama, T. \& Takazawa, T. Effect of methoxyflurane and surgery on human growth hormone and insulin levels in plasma. Can. Anaesth. Soc. J. 17: 347 (1970).

2. Oyama, T. \& Takazawa, T. Effect of diethyl ether anaesthesia and surgery on carbohydrate and fat metabolism in man. Can. Anaesth. Soc. J. 18: 51 (1971). 
3. Oyama, T. \& TAKazawa, T. Effects of halothane anaesthesia and surgery on human growth hormone and insulin levels in plasma. Br. J. Anaesth. 43: 573 (1971).

4. Schalch, D.S. \& Parker, M.L. A sensitive double antibody immunoassay for human growth hormone in plasma. Nature 203: 1141 ( 1964 ).

5. Morgan, C.R. \& Lazarow, A. Immunoassay of insulin: two antibody system. Diabetes 12: 115 (1963).

6. Rudd, B.T., SAMPSON, P., \& BRooke, B.N. A new fluorimetric method of plasma cortisol assay with a study of pituitary-adrenal function using metyrapone (S.U. 4885). J. Endocrinal. 27: 317 (1963).

7. Byles, P.H., Dobrin, A.B., \& Jones, D.B. Forane (Compound 469): 3. Comparative effects of prolonged anaesthesia on mature beagle dogs and young rhesus monkeys. Can. Anaesth. Soc. J. 18: 397 (1971).

8. Dobkin, A.B., Byles, P.H., Ghanooni, S., \& Valbuena, D.A. Clinical and laboratory evaluation of a new inhalation anaesthetic: Forane (Compound 469) $\mathrm{CHF}_{2}-\mathrm{O}-\mathrm{CHClCF}_{3}$. Can. Anaesth. Soc. J. 18: 264 (1971).

9. Oyama, T., Takiguchi, M., \& Kudo, T. Metabolic effects of anaesthesia: effect of thiopentone-nitrous oxide anaesthesia on human growth hormone and insulin levels in plasma. Can. Anaesth. Soc. J. 18: 442 (1971).

10. Oyama, T., Shibata, S., Matsumoto, F., \& Kudo, T. Adrenocortical function related to methoxyflurane anaesthesia and surgery in man. Can. Anaesth. Soc. I. 15: 362 (1968).

11. Oyama, T., Shibata, S., Takiguchi, M., \& Kudo, T. Effects of halothane anaesthesia and surgery on adrenocortical function in man. Can. Anaesth. Soc. J. 15: 258 (1968).

12. Oyama, T., Matsuki, A., \& Kudo, M. Effect of ethrane anaesthesia and surgery on adrenocortical function. Can. Anaesth. Soc. J. 19: 394 (1972). 